\title{
The Evaluation of Physical, Sports and Health Education (PSHE) Online Learning Implementation at the Junior High School Level in Sumbul District During Covid-19 Pandemic Period for the 2020/2021 Academic Year
}

\author{
Lokakarsa Purba ${ }^{1, *}$ Nimrot Manalu ${ }^{2,}$ Muhammad Irfan ${ }^{3}$
}

\author{
${ }^{1}$ Program Magister Pendidikan Olahraga, Universitas Negeri Medan, Medan, Indonesia \\ ${ }^{2}$ Program Magister Pendidikan Olahraga, Universitas Negeri Medan, Medan, Indonesia \\ ${ }^{3}$ Program Magister Pendidikan Olahraga, Universitas Negeri Medan, Medan, Indonesia \\ *Corresponding author. Email: karsapurba@gmail.com
}

\begin{abstract}
This study aims to describe the implementation of Physical, Sports and Health Education (PSHE) online learning at the State Junior High School in Sumbul Regency, measured from the Context, Input, Process and Product variables. This research is a descriptive evaluative research. The subjects of this study were the principal of 5 people, 5 people of PSHE teachers and 162 class VIII students, the sample was taken by purposive sampling. Data were collected using observation, questionnaires, interviews and documentation. The data analysis technique used is descriptive analysis technique. The results showed 1. Context aspect showed Policy (100\% Principal, 80\% Teacher), Objectives (95\% Principal, 80\% Teacher, Student $84.10 \%$ ), Guidelines (100\% Principal, Teacher $83.75 \%$ ). 2. The input aspect shows teacher competence (teachers $79.29 \%$ ), student abilities (teachers $73.75 \%$, students $79.75 \%$ ), infrastructure facilities (principals $73.75 \%$, teachers $65 \%$, students $76 \%$ ). 3. Process aspect shows the stages of pre-learning implementation (Principal 78.75\%, Teacher 80\%, Student 82.91\%), Stages of implementation during learning (Principal 81.66\%, Teacher $78.75 \%$, Student $79.68 \%$ ), Stages of implementation after learning (Principal 78.33\%, Teachers $77.86 \%$, Students 78.24\%). 4. Product aspect shows the completeness of online PSHE learning outcomes (principals $72.14 \%$, teachers $78.13 \%$, students $75.21 \%$ ). Based on the results of the study, it was concluded that the implementation of PSHE online learning at the State Junior High School in Sumbul Regency as a whole had been carried out well.
\end{abstract}

Keywords: Learning Evaluation, Physical Education, Online Learning, CIPP Model Evaluation.

\section{INTRODUCTION}

Physical, Sports and Health Education (PSHE) is one part of the subjects given in high school, junior high school and elementary school. According to UNESCO, PSHE is a process of human education as individuals or community members carried out consciously and systematically through various physical activities in obtaining increased physical abilities and skills, growth, intelligence and character development, as well as according to the Ministry of National Education [1] PSHE as an educational process that utilizes physical activity must be planned systematically to develop and improve individuals organically, neuromuscularly, perceptually, cognitively, socially, and emotionally within the framework of the national education system. When concluded, physical education is education through physical or physical activities that are systematically planned to achieve educational goals by increasing the psychomotor, cognitive, and affective domains. PSHE has a very important role in intensifying the implementation of education as a process of human development that lasts a lifetime. PSHE as a medium to encourage motoric development, physical ability, knowledge and reasoning, appreciation of values (attitude-mental-emotional-spiritual- and social), as well as the habituation of healthy lifestyles that lead to stimulating growth and balanced development. 
The impact of the Covid-19 pandemic, On March 24, 2020, The Indonesian Minister of Education and Culture stated a policy No. 4 of 2020 concerning the implementation of education policies in the emergency period of the spread of Covid-19, it was explained that the learning process was carried out at home. through online or online learning. This is done to prevent the spread of the Covid-19 virus. To strengthen this circular, The Indonesian Ministry of Education and Culture issued a policy No. 15 of 2020 regarding guidelines for implementing learning from home in the emergency period of the spread of Covid-19. The existence of the Covid-19 pandemic requires educational institutions to innovate in the learning process. One form of innovation is to conduct distance or online learning. The steps for implementing distance learning by educators consist of 3 stages, namely prelearning, during learning and after learning.

According to Thome "online learning is learning that in the learning process uses multimedia technology, virtual classes, videos, animated online texts, email, voice messages, telephone conferences, and online video streaming" [2]. In line with Asmuni's opinion [3] "the online learning system is a learning system without face to face directly between teachers and students, but online using the internet network". In online learning, teachers and students learn together, at the same time, using various applications, such as Whatsapp, Edmodo, Telegram, Zoom Meeting, Google Meet, Google Classroom, Quiepper School, Ruang Guru and other applications" [4]. Online learning is a new challenge for educators during this pandemic, which requires them to be able to use online learning media, to be able to carry out online learning and is expected to be able to increase their creativity in the learning process. To carry out learning in the network or online, all parties who take part in the learning process. Online learning must be planned, implemented, and evaluated as well as learning that occurs in the classroom. Planning can be defined as the process of compiling subject matter, using teaching media, using teaching approaches and methods, and assessing in a time allocation that will be carried out at a certain period to achieve predetermined goals.

The results of the researchers' initial observations, namely there was a direct order from the Dairi District Education Office (Dairi Regent Circular No: 800/3120, 2020) dated July 10, 2020, as the background for learning from home so that online-based learning was planned. Furthermore, from interviews with principals in Sumbul District and teachers at State Junior High Schools in Sumbul District, they explained that from the two learning programs during the Covid-19 emergency, online learning was determined during study from home. Based on the mobile phone verification of the Ministry of Education and Culture, there are 41 teachers and 792 students with cell phone numbers at SMP Negeri 1 Sumbul, there are 35 teachers and 492 students with cellphone numbers at SMP Negeri 2 Sumbul, there are 34 teachers and 635 students with cellphone numbers at SMP Negeri 3 Sumbul, there are as many as 22 teachers and 338 students with cell phone numbers at SMP Negeri 4 Sumbul and there are as many as 11 teachers and 335 students with cell phone numbers at SMP Negeri 5 Sumbul have carried out mobile phone verification by the Ministry of Education and Culture. While the implementation of online learning that is carried out is by using google meet and zoom as virtual face-to-face to interact directly, using whatsapp groups as a medium of communication interaction, using google classroom for learning management (material assignments, assignments and assessments). It can be concluded that the implementation of learning during the Covid-19 pandemic emergency, students still have the right to inclusive education services without being burdened by the completeness of curriculum achievements and avoiding Covid-19. The courage to be creative in implementing the curriculum in the normal adaptation era in accordance with the Covid-19 pandemic situation, PSHE learning continues according to health protocols with the main target (temporarily) being more on fitness and motor skills [5].

To describe the initial facts in the field of implementing online learning referred to by the principals of the Dairi Regency, the researchers distributed questionnaires via Google forms to students in SMP in Sumbul District as participants. From the results of distributing questionnaires from 50 students who participated in filling out the questionnaire, there were $96.8 \%$ doing learning from home (BDR), there were $76 \%$ using gadgets/devices and laptops. Then according to the results of the questionnaire that describes the facts of the implementation of online learning in public junior high schools throughout the Sumbul District, $83.7 \%$ chose to receive learning information through the WA Group, $61.6 \%$ chose to do assignments using google classroom and $23.3 \%$ chose to do face-to-face using google meet and zoom.

Judging from the content and subjects taught in schools during the pandemic, there are two different groups in the application of online learning, the first group is a group of subjects that is dominated by theory and little practice, while the second group is dominated by practice with little theory, namely PSHE subjects. . The essence of PSHE learning requires physical movement, the learning is carried out in open spaces or in the field. The method for PSHE is the deductive method or the command method, with various assignments, demonstrations and a little explanation. Various limitations on internet access, and operational capabilities on online features, physical education naturally encountered various obstacles and obstacles during the covid-19 pandemic. PSHE teachers throughout the Sumbul District are of the opinion that Before the Covid-19 pandemic, learning was mostly 
carried out outside the classroom or outside school for schools that did not have a field, after the pandemic the implementation of PSHE learning experienced many obstacles, PSHE learning turned into online learning which had limited access internet and operational capabilities on online features and cannot be carried out haphazardly outdoors without complying with the health protocols that have been set by the government. From this opinion, the researcher suspects that the barriers to PSHE's online learning are due to limited abilities regarding the stages of online learning and the use of the internet by teachers and students as well as limited facilities and infrastructure so that it needs to be investigated. Educational HR must be able to adapt to online learning technology, which can lead students to learn independently without ignoring the quality of learning. Especially the PSHE material must be able to adapt to these conditions, which used to be before the covid-19 pandemic outbreak the practical learning process in the school field [6].

Based on the researchers' initial observations in the field, PSHE online learning in public junior high schools throughout the Sumbul District has never been implemented by both teachers and students, the learning system carried out before the Covid-19 emergency period was a conventional or face-to-face learning system in accordance with the 2013 curriculum. , educators already have good competence seen from the level of education, namely strata 1 bachelor of education but have never studied online learning systems before. Furthermore, teachers at State Junior High Schools throughout the Axis District revealed that before implementing PSHE online learning, first ensure that students have and master the facilities needed in PSHE online learning even though there are still obstacles faced by students. There are several obstacles faced by students during PSHE online learning according to the researchers' initial observations, including lack of concentration $(68.1 \%$ of answers), boring (33.5\% of answers), too many tasks (31.4\% of answers), not so proficient in using learning technology $(28.4 \%$ of answers), no one to accompany (29.9\% of answers), a fixed schedule $(29.1 \%$ of answers), no internet access $(16.8 \%$ of answers) and no internet quota $(18.7 \%$ answers). The problems faced by elements of education in public junior high schools throughout the Sumbul District are not only from the decision to implement the PSHE online learning program, but the readiness of educators and students affects the learning process.

Evaluation is an activity to find out the extent to which the planned program has been implemented, what are the obstacles and how to overcome the problem [7]. Program evaluation is an effort to determine the level of implementation of a policy carefully by knowing the effectiveness of each of its components [8]. The benefits of program evaluation are "collecting the right data so that it can be continued by providing the right guidance"
[8]. Evaluation of learning programs is a systematic and continuous process to collect, describe, interpret, and present information about the implementation of learning program designs as a basis for making decisions [9]. From the statements of the experts above, it can be seen that the evaluation of a learning program is an activity to collect information about the performance of the components of a physical education learning program as a basis for making decisions. There are several evaluation models, including the evaluation of the CIPP model (Context, Input, Process, Product) developed by Stufflebeam. The evaluation of the CIPP model includes a categorization of system evaluation starting from the view that the success of a program is influenced by several factors [10].

This study aims to evaluate how the implementation of PSHE online learning in public junior high schools throughout the Sumbul District during the Covid-19 emergency which includes the context of online learning policies, online learning objectives and PSHE online learning guidelines. In terms of input of teacher competence, student abilities, and infrastructure in implementing PSHE online learning. In terms of the process that needs to be evaluated, the stages of implementing online learning such as the stages of implementing pre-learning, during learning and after learning and finally in terms of product achievement of complete learning outcomes online PSHE students learning PSHE online from home during the COVID-19 emergency. Based on the background of the problems that have been stated above, it is necessary to evaluate the implementation of PSHE online learning during the COVID-19 emergency period in State Junior High Schools throughout the Sumbul District for the 2020/2021 Academic Year.

\section{RESEARCH METHODS}

This research is an evaluative descriptive research which uses an evaluation research method with the aim of assessing and testing the implementation of a program or the effectiveness of a program. this is in accordance with what $i$ is explaining that the aim of research is to evaluate ieducation i to design, to perfect, and also to test the implementation of a $\mathrm{i}$ education practice, i.e. education, practice, education otherwise. The evaluation model used in this study is the Context, Input, Process, Product (CIPP) Evaluation Model, which is the most widely known and applied model by evaluators. The evaluation of the CIPP model can be applied in various fields, such as education curriculum, management, companies, and so on as well as at various levels, be it projects, programs or institutions. CIPP evaluation is a process of describing, finding, providing descriptive information, considering the value and benefits of several goals that have been planned, 
implemented, and their effects to guide a decision, assess accountability, and understand phenomena [11].

This research will be carried out at State Junior High Schools in Sumbul District, which consists of 5 schools, namely: SMP N 1 Sumbul, SMP N 2 Sumbul, SMP N 3 Sumbul, SMP N 4 Sumbul and SMP N 5 Sumbul in subjects COPD. The subjects in this research are the principal of the school, the teacher of PSHE and the student of grade VIII in Sumbul District.

This study only uses a part of the subject or population. According to Suharsimi Arikunto [12], some or irepresentatives of the population studied are samples. The sample to be taken includes all 5 principals of iSMP Negeri in Sumbul District, 5 people, PSHE subject teachers in every SMP Negeri Ise-District of Sumbul, 5 people and study groups (classes) selected by purposive sampling technique. where purposive sampling is a research sampling technique with criteria which have been determined based on research objectives [13]. The researcher used special conditions to take samples of students, namely 1 class VIII (eight) from every public junior high school in Sumbul District where class VIII SMP Negeri 1 Sumbul with a total of 32 students, class VIII SMP Negeri 2 Sumbul i with a total of 32 students, class VIII SMP Negeri 3 with a total of 34 students, class VIII SMP Negeri 4 with a total of 32 students, and class VIII SMP Negeri 5 with a total of 32 students, so from these data it can be concluded that the number of student samples is 162 students.

Research instruments are tools that can be used to measure natural or social phenomena that are being observed [14]. The instrument used in this research is a questionnaire and interview instruments. The instrument aims to evaluate the implementation of PSHE online learning in State Junior High Schools throughout the Sumbul District in the 2020/2021 Academic Year. The researcher determines the criteria for each component, then the instrument is submitted to the expert/validator to be assessed and given input.

Evaluation of the Online Physical Education Learning Program at West Nias Regency Public High School using the CIPP Evaluation Model, which is divided into 4 CIPP evaluation models, which are as follows:

\section{1) Context}

Context evaluation is limited to online learning policies, goals, and needs. In this study, context evaluation is to see the implementation of online learning according to policies, with online learning objectives, and the needs needed in online learning programs.

\section{2) Input}

The input evaluation is limited to describing the condition of the teacher, the condition of the students, and the facilities and infrastructure. In this study, the evaluation of the input in question is to determine the condition of the teacher and the condition of the students in carrying out activities and describe the state of the facilities and infrastructure in the online learning program.

\section{3) Process}

Process evaluation is limited to learning preparation, learning process, sincerity, enthusiasm, and motivation. In this study, the evaluation process in question is to find out the process of implementing online physical education learning as seen from the preparation of teacher and student learning, implementation of teacher and student learning, teacher seriousness in teaching and students' seriousness in learning, teacher's enthusiasm in teaching and students' enthusiasm in learning, as well as teacher's motivation in teaching and student motivation in learning.

\section{4) Product}

Product evaluation is limited to online learning outcomes. In this study, product evaluation is intended to determine the results of online learning outcomes. Product evaluation is an assessment carried out in order to see the success of a program. From the evaluation, the variables in this study which consist of context indicators, input indicators, process indicators and product indicators can explain the purpose of research on online physical education learning evaluations. So that an evaluator can determine or provide recommendations to certain parties from the results of the evaluation. which has been done.

The data analysis technique used in this research is descriptive analysis, namely by describing and interpreting the data from each of the evaluated aspects. The data collected were analyzed by quantitative descriptive analysis techniques in accordance with the evaluation model used in this study, the results of the research analyzed were described by data analysis techniques for each aspect.

The steps used in analyzing the collected questionnaire data are: (1) scoring the results of the questionnaire; (2) adding up the total score of each aspect; (3) grouping the scores obtained based on the level of tendency; and (4) look at the percentage of each trend with the existing categories, so that information about the results of the study is obtained. Scoring and evaluation uses a scale of 4 , namely $1,2,3$, and 4 . The data obtained through observation is assessed by looking at trends. 
Meanwhile, the interview data and documentation were analyzed descriptively qualitatively through the following stages: (1) data reduction; (2) data presentation; and (3) drawing conclusions [14].

\section{Data Reduction}

Data reduction means summarizing, choosing the main things, focusing on the important things, looking for themes with patterns. Thus the data to be reduced provides a clearer picture, and makes it easier for researchers to collect further data and look for it when needed [14].

The data obtained from the field is quite a lot. For this reason, it should be recorded carefully and in detail. The longer the field, the greater the amount of data, complex and complicated. For this reason, it is necessary to analyze the data through data reduction. In this stage the writer will summarize, choose the main things, focus on the things that are important and look for patterns. Thus, the reduced data will provide a clearer picture and make it easier for researchers to conduct further data collection.

\section{Data Presentation}

After the data obtained is reduced or summarized, the next step is the presentation of the data which is a structured set of information that provides the possibility of drawing conclusions and taking action. The presentation of the data is directed so that the reduced data is organized, arranged in a relationship pattern so that it is easier to understand. By displaying the data, this will make it easier to understand what will happen, plan further work based on what has been understood.

\section{Data Verification}

At this stage is the stage of drawing conclusions from all the data that has been obtained as a result of the research. Drawing conclusions or verification is an attempt to find or understand the meaning or meaning, regularities, patterns, explanations, causal paths or propositions. After verifying the data, conclusions can be drawn based on the research results presented in narrative form. Drawing conclusions is the final stage of data analysis activities. Drawing this conclusion is also the final stage of data processing.

\section{Data Triangulation}

Patton states that triangulation with sources "means comparing and double-checking the degree of trustworthiness of information obtained through different times and tools in qualitative research".

With the triangulation technique with sources, the researchers compared the results of the questionnaires obtained from each source or research informant as a comparison to check the truth of the information obtained. The triangulation of the research sources were students, teachers and school principals from each research subject.

\section{RESULTS AND DISCUSSION}

The Online Learning Program is a new program that has been established by the government since the Covid-19 pandemic occurred to all levels of education including State Junior High School Level in Sumbul District. The online learning program that utilizes online-based distance learning is an issue that is still new to every school. For the achievement of optimal learning outcomes in every learning subject, including Physical Education, Sports and Health, it is necessary to design, implement, and provide support for the components.

Online PSHE learning can be carried out properly and is determined by several elements, including: students, teachers, methods, supporting environment, infrastructure, curriculum, goals, and assessments [15]. In this research, the success of PSHE learning is carried out through an evaluation process using the CIPP method (Context, Input, Process, Product). The success criteria as a result of the evaluation of this research are categorized into several groups, including: Very good, Good, Category Enough and Less. The expected result of the evaluation is the value interval in the category "Good" for each component.

\subsection{Evaluation of Context Aspect}

\subsubsection{Online Learning Policy}

All public junior high schools in all Sumbul subdistricts apply online learning in each school - each school follows the government's policy of implementing online learning (Circular Letter Number 4 of 2020, Indonesian Minister of Education and Culture, 2020), (Secretary General Circular No. 15, 2020) and an online learning policy (Dairi Regent Circular No: 800/3120, 2020) which establishes a model for managing education units in the implementation of online learning by instructing teachers to work and teach from home, all students learn from home.

\subsubsection{Online Learning Goals}

The purpose of implementing online learning during the Covid-19 pandemic emergency is so that students continue to get the right to inclusive education services without being burdened by the completeness of curriculum achievements and avoiding Covid-19. The courage to be creative in implementing the curriculum in the normal adaptation era in accordance with the Covid-19 pandemic situation, PSHE learning continues according to health protocols with the main target (temporarily) more on fitness and motor skills [5]. 


\subsubsection{Online Learning Guidlines}

Every school in the Sumbul District Junior High School and PSHE teachers who carry out the online learning process in accordance with the Circular Letter of the Minister of Education and Culture Number 4 of 2020 and the second statement The implementation of online learning in schools is guided by the Secretary General Circular of the Minister of Education and Culture Number 15 of 2020.

However, obstacles were found from the results of interviews with school principals in implementing online learning in accordance with the Secretary General Circular of the Minister of Education and Culture Number 15 of 2020 such as teachers aged 50 years and over being less able to adapt to new habits of implementing information and communication technology-based learning, quotas the internet, student gadgets, the lack of parental roles to assist students in carrying out online learning are constrained, considering that the majority of students' parents are farmers whose knowledge of gadgets, internet and online learning applications is minimal.

\subsection{Evaluation of Input Aspect}

\subsubsection{Facilities and Infrastructure}

From the indicators of facilities and infrastructure, all teachers already have gadgets / devices / laptops / computers and have internet and electricity networks that support the implementation of online PSHE learning. On average, students also already have gadgets/ devices/ laptops/ computers but not completely and some students have to share their cellphones with their siblings, internet network access is unstable/slow network especially if the electricity goes out, there is no internet connection at all there is a very bad internet network and sometimes the electricity goes out too. So it becomes an obstacle in learning. As well as complaints from parents, most of them are the procurement of credit or internet quota. Especially if the student's parents have approximately 3 children, the quota must be bought.

\subsubsection{Teacher's Competencies}

Based on the results of data collection in the form of questionnaires and interviews, information on teacher competence was obtained about the background and experience of PSHE teachers at SMP Negeri Sumbul District. It is known that all PSHE subject teachers are in accordance with the latest educational disciplines, namely Bachelor of Education (S1) majoring in Sports Education, Physical Education, Health, and Sports Coaching Education study programs and an average of 1 to 5 years of teaching experience. Able to implement PSHE learning online, by increasing capacity by participating in online training provided by the government and non-government institutions, and skilled in using gadgets and laptops/computers to support the implementation of PSHE learning online by participating in online webinars such as Indonesian Teacher Association (Ikatan Guru Indonesia).

Able to utilize information and communication technology for the implementation of online PSHE learning, Able to use virtual face-to-face via video conference, teleconference in social media groups or messaging applications to interact directly with students, and Able to use Learning Management System (LMS) applications through activity applications learning for managing and monitoring integrated learning online.

\subsubsection{Students' Ability}

Students' ability to carry out online learning is already supportive, but it was found that students did not understand how applications work and communication rules in the online PSHE learning process, 37 who answered no.

\subsection{Evaluation of Process Aspect}

The results of questionnaire data analysis and interviews with principals, PSHE teachers and students, showed that the online PSHE learning process had a total score of 238.16 with a score of $79.39 \%$. These results indicate that the online learning process of PSHE in SMP Sub-district Sumbul is good.

\subsubsection{Learning Preparation}

The results obtained from questionnaires and interviews with principals and PSHE teachers of SMP Negeri Sumbul Sub-district are already understanding how to use, manage and carry out interactions with students in online PSHE learning using the Learning Management System (LMS) application media Google Classroom, Whatsapp, video conference zoom and google meet.

The results obtained from questionnaires and interviews with all students of SMP Negeri Sumbul District are regarding the preparation of online learning, almost all student preparations have been smooth and good in participating in PSHE learning online by always ensuring internet connections, internet quotas and good gadget batteries when learning is about to starts and preparation of other students to take part in online learning is that students are ready to follow the lessons given by my teacher within the allotted time and take the time, as well as what should be needed when learning begins such as gadgets / gadgets / laptops / computers, and preparing writing styles such as books, pens, necessary tools and others. However, there are 
also some students who are not very ready for online learning due to personal reasons.

\subsubsection{Learning Process}

The results obtained from questionnaires and interviews with all school principals of SMP Negeri Sumbul District, namely the principal ensures that all PSHE teachers and students in their respective schools carry out PSHE learning online by instructing teachers to make reports on the implementation of online learning and hold regular meetings about online learning and directly monitor the online learning process by joining the school principal in the WhatsApp and Google Classroom groups for each class, instructing the teacher to make reports on the implementation of online learning and evaluate them regularly.

The results obtained from questionnaires and interviews with all PSHE teachers at SMP Negeri Sumbul, namely teachers check student attendance and ensure students are ready to take PSHE online learning, guide students to pray before and after PSHE learning during virtual face-to-face, deliver material virtually using zoom / google meet, communicate with the parent/guardian of students or students to ensure that each student can take PSHE online learning and student assignments, always monitor student activities in participating in PSHE learning online through the LMS google classroom and open consulting services for students who have difficulty in carrying out PSHE learning online and always providing feedback to students so that students are more enthusiastic and motivate students in learning. However, problems were also found regarding students who rarely attended virtual meetings using zoom/google meet for various personal reasons.

\subsubsection{After Learning Process}

The results of questionnaire data analysis and interviews with school principals, PSHE teachers and students, showed that the online PSHE learning product had a total score of 225.34 with a score of $75.11 \%$. These results indicate that the online PSHE learning product at the Sumbul District Junior High School is good.

\subsection{Discussion of Every School}

Evaluation of online learning PSHE at SMP Sumbul District encountered several obstacles, such as requiring facilitation, namely Smartphones or laptops, but there were some students who did not have smartphones or laptops plus there was no internet quota to do online learning. This became a big problem for teachers and students. . In addition, with online learning, teachers are also overwhelmed in applying what methods will be delivered in online learning so that students understand the material presented because online learning is not done face-to-face. Online learning is less effective because there are reasons for students who have no network, no signal, no devices such as cellphones or laptops. Therefore, teachers find it difficult to carry out this online learning process. Every student really wants to learn calmly and easily understood in the online learning process. However, teachers are also confused about how online learning can be carried out without any obstacles and does not become a burden for students.

\section{Advantages of Online Learning}

1. Avoiding disease outbreaks that are currently happening.

2. More time with family, of course this will strengthen the relationship with the family.

3. For students, the material sent by the teacher in the form of a video can be repeated if it is not understood.

4. or teachers, videos that have been made can be distributed to the next class that requires the same material.

\section{Disadvantages of Online Learning}

1. Students' understanding of the material is lacking.

2. Teachers find it difficult to monitor student learning progress.

3. Less interaction between teachers and students.

4. Spend a lot of internet quota.

5. Not all students have online learning facilities.

\section{Student Parents' Response to Online Learning}

1. Parents spend more time with their children.

2. Online learning makes parents more cohesive with their children.

3. Parents cannot accompany their children to study when they are busy at work.

\section{Barriers to Teachers Doing Online Learning}

1. Lack of student understanding when conducting the online learning process.

2. Lack of facilities owned by students when studying online.

3. Internet quota that cannot be reached by all students.

4. Signal limitations can hinder the teaching and learning process in online learning.

\section{CONLUSIONS}

Based on the results of data analysis and research discussions that have been described, it can be concluded that the implementation of online PSHE learning at the Sumbul District Junior High School is obtained by a percentage of $79.30 \%$ which is stated to be in good category, with principal respondents stated in the very good category, teacher and student respondents carry out PSHE online learning in the good category. 


\section{ACKNOWLEDGMENTS}

On this occasion the authors would like to express their sincere thanks and highest appreciation to all those who have helped the author: Mr. Dr. Nimrot Manalu, M.Kes as the supervisor I and Mr. Dr. Muhammad Irfan, S.Pd, M.Or. as the supervisor II.

\section{REFERENCES}

[1] Depdiknas. (2004). Kurikulum Satuan Pendidikan. Pendidikan Jasmani. Ditjen Dikdasmen Direktoral.

[2] Kuntarto, E. (2017). Keefektifan Model Pembelajaran Daring dalam Perkuliahan.

[3] Asmuni, A. (2020). Problematika Pembelajaran Daring di Masa Pandemi Covid-19 dan Solusi Pemecahannya. Jurnal Paedagogy, 7(4), 281-288.

[4] Enriquez, M. A. S. (2014). Students 'Perceptions on the Effectiveness of the Use of Edmodo as a Supplementary Tool for Learning. DLSU Research Congress.

[5] Sinulingga ,Albadi. (2021). TPACK dalam Kurikulum PJOK (D. Dr. Budi Valianto (ed.); Revisi). Perdana Publishing.

[6] Bangun, S. Y. (2021). Peranan Iptek Dalam Pembelajaran Pjok Di Era New Normal Pandemic COVID-19. Perdana Publishing.

[7] Dedi Asmajaya, Agung Sunarno, S. H. (2020). Pelajaran Penjas Di Smp Negeri Se-Kecematan. 06, 43-50.

[8] Suharsimi Arikunto dan Cepi Safruddin. (2010). Evaluasi Program Pendidikan. Bumi Aksara.

[9] Widoyoko, E. P. (2009). Evaluasi Program Pembelajaran. Pustaka Belajar.

[10] Ali, Mohammad. (2014). Metodologi dan Aplikasi Riset. PT. Bumi Aksara.

[11] Mulyatiningsih, Endang. (2012). Riset terapan bidang pendidikan dan teknik. UNY Press.

[12] Suharsimi Arikunto. (2014). Dasar-Dasar Evaluasi Pendidikan Edisi Revisi. Bumi Aksara.

[13] Sriundy, I M. (2015). Metodologi Penelitian. Surabaya: Unesa University Press.

[14] Sugiyono. (2013). Metodologi Penelitian Kuantitatif Kualitatif dan R\&D. Alfabeta.

[15] Suryosubroto. (1990). atalaksana Kurikulum. Rineka Cipta. 